\title{
Method for Evaluating the Effect of the Design and the Environmental Conditions of the Manufacturing Cells to Improve Work Performance
}

\author{
Mildrend Montoya-Reyes ${ }^{(D)},{ }^{1}$ Alvaro González-Angeles iD, ${ }^{1}$ \\ Margarita Gil-Samaniego-Ramos $\mathbb{D}^{1},{ }^{1}$ Ismael Mendoza-Muñoz $\mathbb{D}$, ${ }^{1}$ and Juan Ling-López $\mathbb{D}^{2}$ \\ ${ }^{1}$ Facultad de Ingeniería, Universidad Autónoma de Baja California, Mexicali 21100, Mexico \\ ${ }^{2}$ Universidad Politécnica de Baja California, Mexicali 21376, Mexico \\ Correspondence should be addressed to Alvaro González-Angeles; gangelesa@gmail.com
}

Received 12 November 2019; Revised 10 July 2020; Accepted 25 August 2020; Published 14 October 2020

Academic Editor: Elsa de Sá Caetano

Copyright (c) 2020 Mildrend Montoya-Reyes et al. This is an open access article distributed under the Creative Commons Attribution License, which permits unrestricted use, distribution, and reproduction in any medium, provided the original work is properly cited.

\begin{abstract}
A method is proposed to improve work performance through an adequate design of the manufacturing cell along with optimal environmental conditions to contribute to the well-being of the worker. The methodology used was divided into four stages: the first corresponds to the analysis of operations; the second is the analysis of the effect of the design of the manufacturing cell; the third is the evaluation of environmental conditions such as lighting, noise, and temperature to compare them with the official standard and determine if they meet the permitted levels; and the fourth is to conclude and recommend improvements to the manufacturing cell. The method was applied in a company in the automotive industry, where a change was made from a linear cell distribution to an L-shaped distribution, with a 50\% reduction in workforce and an increase in the productive time of the worker of $49 \%$. Also, the environmental conditions of the cell comply with the requirements of official standards.
\end{abstract}

\section{Introduction}

Globalization has generated competition to position products in the market; therefore, consumers require innovative products with higher quality and availability, which leads companies to seek ways to optimize their processes and standard production times $[1,2]$. The design of the workstation, oriented to the requirements of users and tasks, allows organizations to increase their production indicators (less time, space, and cost) and quality levels [3]; however, the human factor remains the core of the manufacturing system, playing a constant role in the development of Industry 4.0 [4].

It is important to provide a healthy indoor environment that maximizes the comfort, well-being, and work performance of workers [5]. Dul et al. [6] pointed out that human factors/ergonomics (HFE) have great potential to contribute to the design of all types of systems. HFE has a unique combination of three fundamental characteristics: (1) it takes a focus system, (2) it is based on design, and (3) it focuses on two closely related results: performance and well-being.

Research has been conducted on the working conditions of workers in workplaces due to environmental factors and developed measures to improve them [7]. Other research indicates that a harmful work environment causes occupational diseases and fatigue that reduce the quality of work [8].

One of the investigations focused on adapting working conditions to the psychophysiological characteristics of its employees. The planning and development of ergonomic actions took place in three distinctive stages: ergonomic analysis of the workplace (stage 1), ergonomic adaptations (stage (2), and the ergonomic committee (stage (3) [9]. Recommendations for the design of the radiological workplace were provided in another study, where factors such as backlighting and chair position are often 
undervalued in the design and implementation of the radiological workplace [10]. In addition, there was a study that conducted an evaluation of lighting and noise levels, and the study results showed that the worker's age, lighting level, and noise level contribute significantly to task performance [11].

One of the important environmental conditions to evaluate is noise, generally defined as an unwanted sound and perceived as a pollutant and a stressful type of environment. Acute exposure to noise directly causes a number of short-term physiological problems, such as increased blood pressure, increased endocrine secretion, and increased heart rate $[12,13]$. For this reason, it is necessary to constantly evaluate the noise exposure of the workers to avoid affecting the health of the workers [14]. If the environmental conditions in each workplace are adequate, it improves worker satisfaction, work performance, safety, and health [15].

The objective of this study was to analyse the manufacturing cell and evaluate whether its design and the environmental conditions favor the well-being of the worker and their work performance.

\section{Materials and Methods}

Method engineering and ergonomics were used as the basis for a proposal to evaluate the effect of design and environmental conditions on the performance and well-being of workers (Figure 1).

The analysis of operations was carried out with a study of times with a chronometer, represented through an operations diagram to identify the operations and the times in seconds that are required to produce the product. The manufacturing cell design was then evaluated to determine if it was the most suitable for the worker [16].

In the evaluation of the environmental conditions, a matrix of points is carried out on the layout of the manufacturing cell to identify the points where the readings of each factor will be made and then a surface graph with the data obtained is made, which allows observing how its name is indicated by color surfaces according to the level of each factor [17]. The next step is to evaluate whether the factors comply with official standards and finally conclude with improvements to the manufacturing cell that allows for better work performance.

\section{Results and Discussion}

The study was carried out in a company in the automotive industry, specifically in the manufacturing cell that performs two processes: lathe and grinding. Each machine is operated by a worker.

3.1. Operation Analysis. For the analysis, a process operations chart was carried out, which is shown in Figure 2. The distribution of the manufacturing cell is linear, the operators work standing up during a 12-hour shift, the production process for the first piece is 174 seconds, and every 68 seconds each piece is finished. Therefore, the lathe operator stays busy only $23 \%$ of the time and transports the part to the grinding process, and the grinding operator stays in his area working only $35 \%$ of the time. This is in both cases because they are waiting for the machining process.

The study of times allows to identify the type of activities: (a) those that add value, that is, the operations that allow the transformation of the product and must be strengthened; (b) those that do not add value, but are necessary such as inspection and transportation and that is sought to reduce their time; (c) those that do not add value and are unnecessary, such as delays or dead times that are sought to be eliminated to improve the process.

3.2. Manufacturing Cell Design. Because the operators' uptime is very low, it was proposed to eliminate downtime; now, one operator operates both machines, achieving a $49 \%$ increase in the operator uptime. In addition, it was sought to reduce transport, shortening the distance between the machines, and favoring the transfer from one machine to another using an L-shaped distribution, as shown in Figure 3.

This manufacturing cell is at elbow height, and it has enough legroom and antifatigue mats in front of each machine. The possibility of placing a chair [18] was analysed, but it is not recommended for this process because the worker moves from one machine to another.

\subsection{Assessment of Environmental Conditions}

3.3.1. Make the Matrix in Layout. Each manufacturing cell is integrated by a lathe and a grinding machine. Figure 4 shows the layout of two manufacturing cells.

Figure 5 shows how the layout was divided to form a $4 \times 5$-point matrix, to identify each point in the layout where noise, lighting, and temperature of the area will be measured.

3.3.2. Measure Factors: Light, Noise, and Temperature. The ergonomic factors that were measured were the lighting levels, sound levels, and the thermal environment. In Table 1, the measurement instrument and the measurement method for each factor are indicated. It is important to note that any other factor can be evaluated if considered necessary.

3.3.3. Make Surface Graphs. The data obtained from the environmental conditions in each point of the matrix are captured in MS Excel, and the surface graphs are elaborated to project them on the layout of the manufacturing cell.

Figure 6(a) shows the distribution of the manufacturing cells with the areas delimited by lighting levels, and Figure 6(b) shows the area shaded by colors where it can be seen that it corresponds to the visual tasks of the work: blue corresponds to the lighting for interiors such as walkways, and the highest value obtained was 104 lux; red corresponds to a simple visual requirement such as the work of the machine, and the highest value obtained was 220 lux; and green corresponds to a moderate detail distinction as visual inspection, and the highest value obtained was 308 lux. 

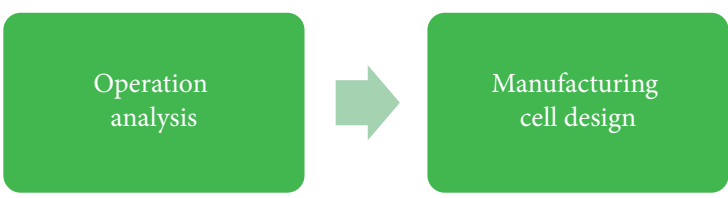

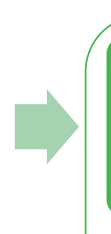

(a) Make the matrix

(b) Measure factors: light, noise, and temperature

(c) Make surface graphs

(d) Evaluate in accordance with the official standard

FIGURE 1: Method of evaluating the effect of the design and the environmental conditions of the manufacturing cells to improve work performance. (a) Make the matrix in the layout. (b) Measure factors: light, noise, and temperature. (c) Make surface graphs. (d) Evaluate in accordance with the official standard.

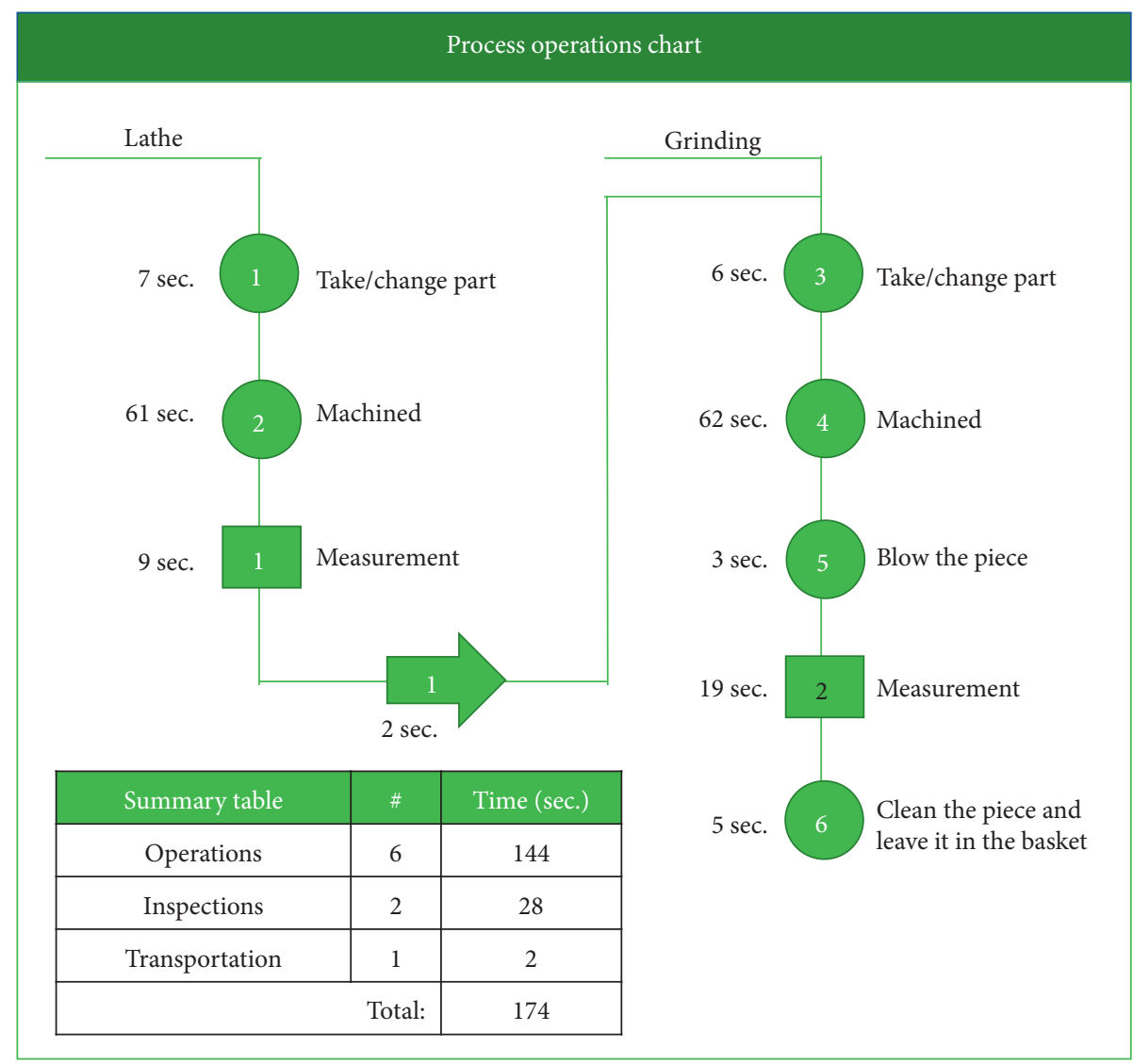

FIgURE 2: Process operations chart of lathe and grinding process.

Figure 7(a) shows the layout with the areas delineated by noise levels, and Figure 7(b) shows the shaded area: red shows levels from 75 to 80 decibels $(\mathrm{dB})$, green shows levels from 80 to $85 \mathrm{~dB}$, and purple shows levels of 85 to $90 \mathrm{~dB}$, which corresponds to the highest noise values, which are due to noise generated by machines.
Figure 8 (a) shows the layout with areas delimited by temperature levels, and Figure $8(\mathrm{~b})$ shows the shaded area: green shows levels from 27 to $28^{\circ} \mathrm{C}$, red shows levels from 27 to $26^{\circ} \mathrm{C}$, both areas correspond to the locations of the machines, and the blue shows levels of 25 to $26^{\circ} \mathrm{C}$ which corresponds to the area where the workers move. In 


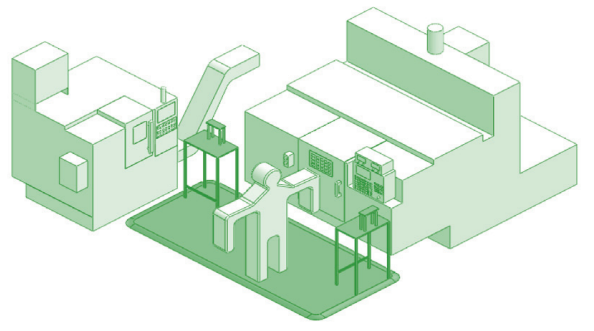

FIgURE 3: L-shaped distribution of the manufacturing cell.

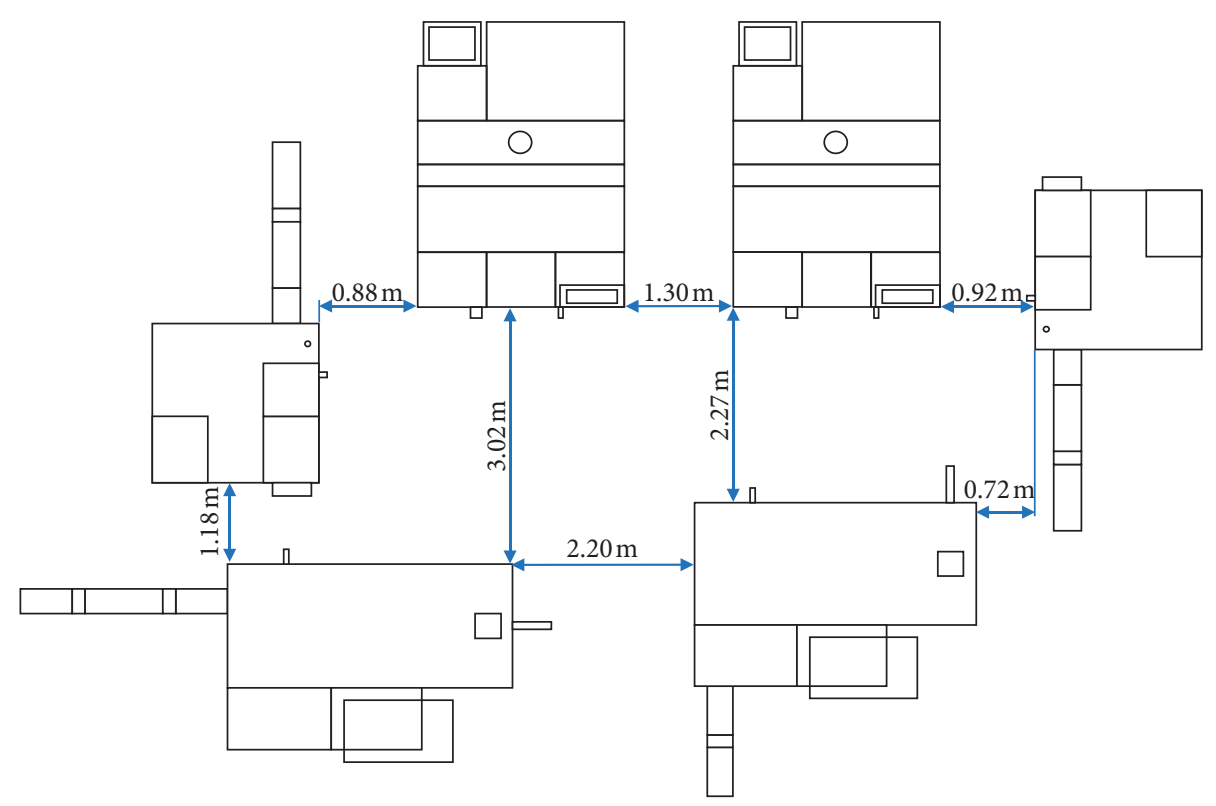

FIgURE 4: Layout of the manufacturing cells.

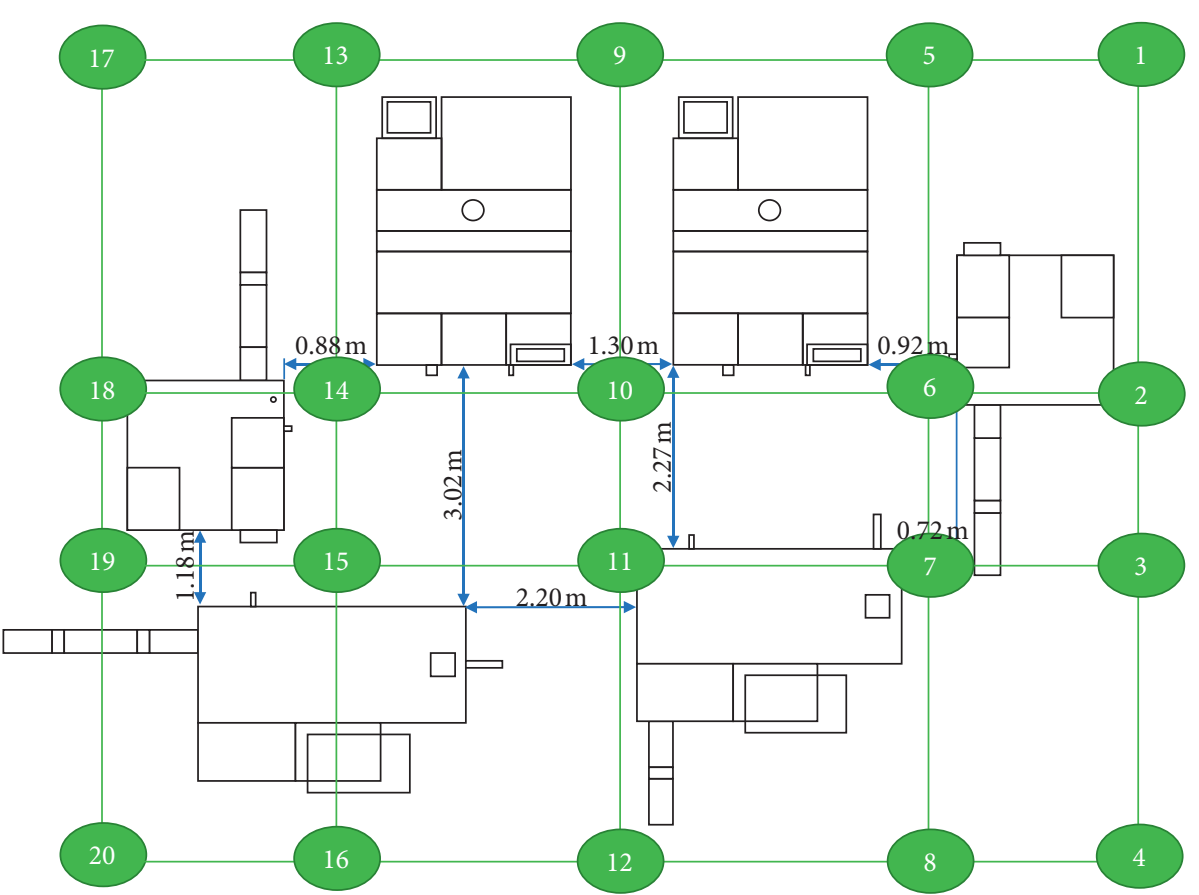

FIgURE 5: 4×5-point matrix. 
TABLE 1: Ergonomic factors, measurement instruments, and measurement method.

\begin{tabular}{ll}
\hline $\begin{array}{l}\text { Ergonomic } \\
\text { factor }\end{array}$ & Measurement instrument \\
\hline
\end{tabular}

Lighting levels

Lux meter

Noise level meter,

Noise levels which allows measuring sounds between 35 and 130 decibels with frequencies between $31.5 \mathrm{~Hz}$ and $8 \mathrm{KHz}$ and a precision of 2 decibels.

Thermometer, which allows measuring the

Thermal environment temperature in ${ }^{\circ} \mathrm{C}$ and the humidity percentage of the work area to determine if there is a risk of thermal stress.
The measurements of the lighting are made at the points indicated in the layout at the height of the work plane, trying not to cast shadow on the lux meter.

The measurements of the maximum sound intensity were made at the points indicated in the layout one meter from the height of the work plane, and the results were noted. Care was taken not to interfere with the body and the imaginary line that connects the sound sources with the

sound level meter's microphone. Also, the position of the sound level meter at the measurement points was always vertical with the pick-up microphone up. The value is read only when the indicator display stabilizes.

The temperature and humidity are taken at the points indicated in the layout at the height of the work plane.

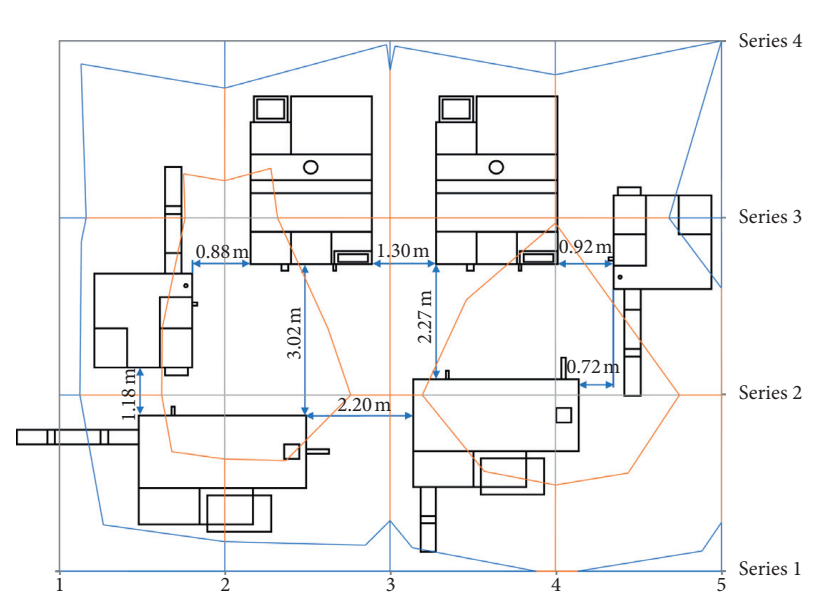

$\square$ 200-300

$100-200$

ㅁ $0-100$

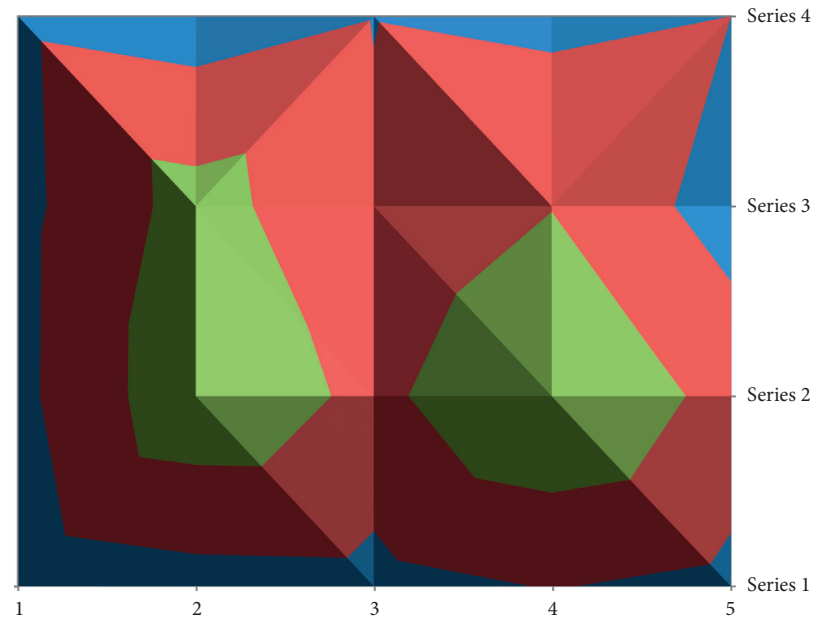

- 200-300

- $100-200$

- $0-100$

(a)

(b)

FIgURE 6: Surface graphs of lighting levels.

addition, the humidity was measured with results of $30 \%$ to $41 \%$.

\subsubsection{Evaluate in Accordance with the Official Standard.} In Mexico, the Official Mexican Standards are used, with respect to the health, safety, and hygiene conditions that must be observed in the workplace. As established by the standards, the results obtained are compared to determine if the company complies or not. Table 2 shows the evaluation that was made to the company, and its results imply that it complies with the requirements of the official standard.

3.4. Improvements to the Manufacturing Cells. The analysis of operations was carried out with which the change in the 


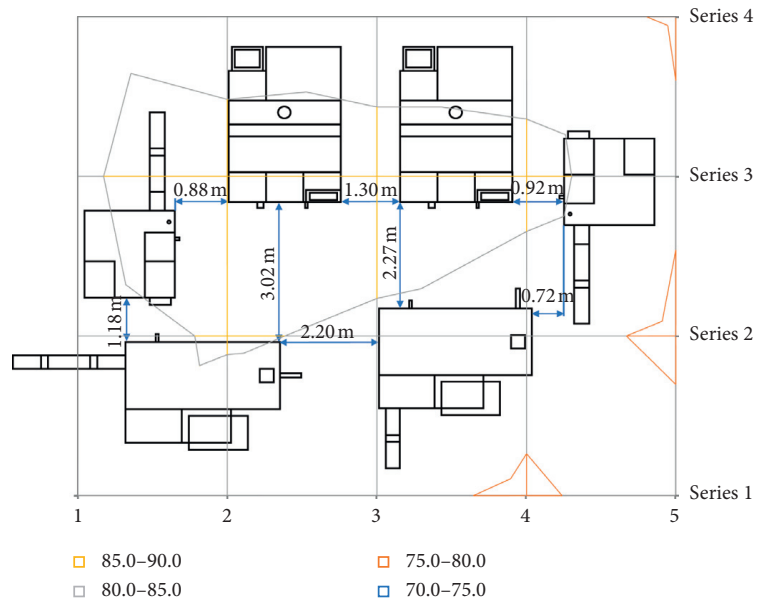

(a)

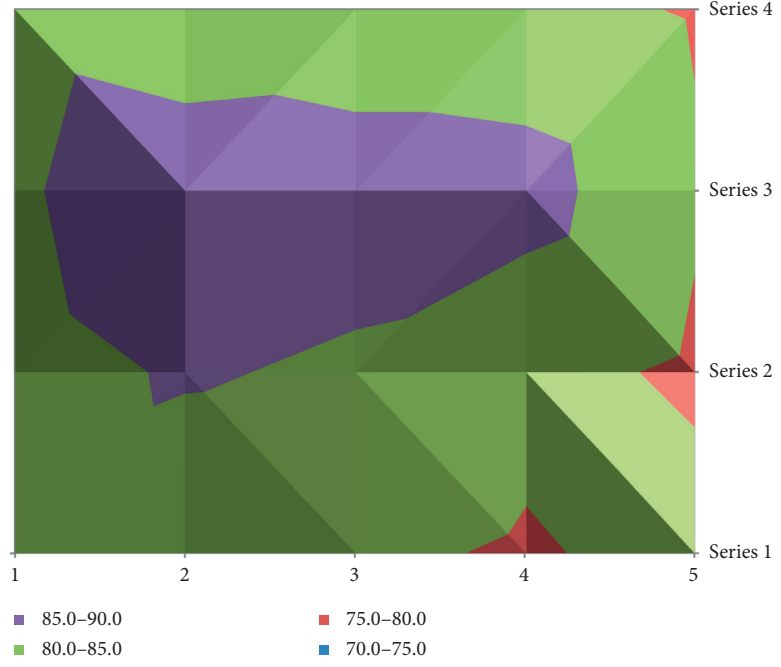

(b)

Figure 7: Surface graphs of noise levels.

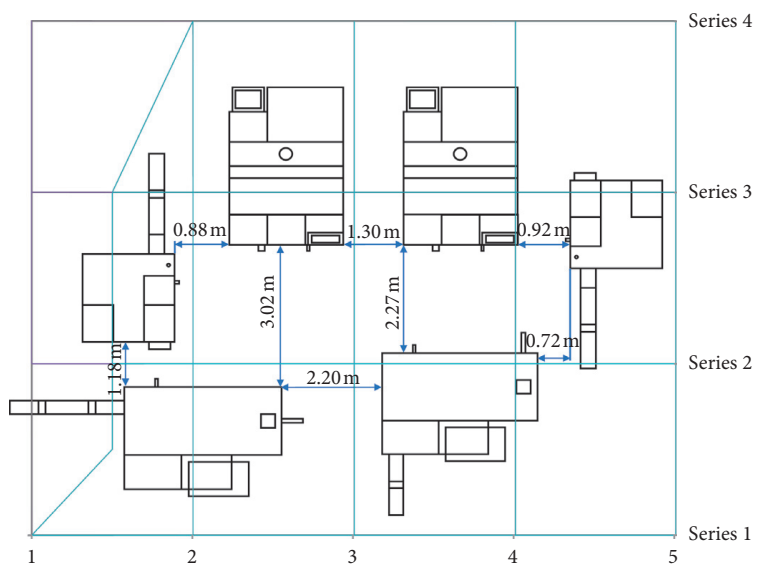

口 26-27

$\square$ 25-26

$\square 24-25$

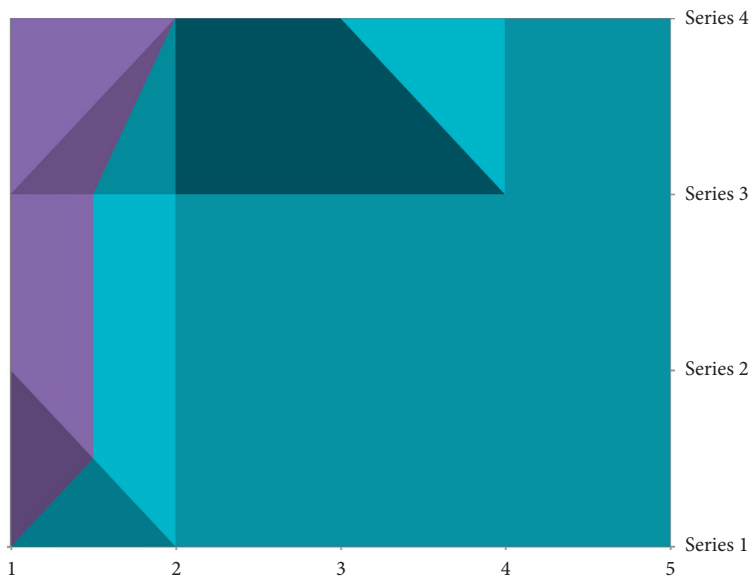

- $26-27$

- $25-26$

- $24-25$

(a)

(b)

Figure 8: Surface graphs of temperature levels.

distribution of the manufacturing cell from linear to L-shaped was made, and there was a reduction of labor of $50 \%$. Therefore, the operator's working time increased $49 \%$, the distances between the machines were shortened, the space was optimized, and the operator who would no longer have to stand alone in front of the machine, now he has movement from one machine to the other, allowing him to move his legs more, which is of greater benefit to counteract fatigue. It was also recommended to use an antifatigue mat that covers the area through which the worker walks as shown in Figure 2.

When evaluating the lighting levels, noise levels, and the thermal environment in the manufacturing cells, it was identified that they comply with those required by the Official Mexican Standard. However, the use of LED lamps is recommended to optimize their systems [23]. Regarding noise, it is important to note that it does not exceed $90 \mathrm{~dB}$, but the exposure is greater than 8 hours; therefore, operators use earplugs. Due to the type of processes that the workplace uses, it is kept refrigerated, the standard indicates up to $26^{\circ} \mathrm{C}$ in hot weather and readings of up to $30^{\circ} \mathrm{C}$ were obtained, which is why the official standard on maximum permissible limits of exposure to high thermal conditions, which indicates that the maximum allowable temperature in a light work regime is $30^{\circ} \mathrm{C}$. Therefore, the temperature does not affect work performance. 
TABLE 2: Evaluation of compliance with official standards.

\begin{tabular}{|c|c|c|c|c|}
\hline Ergonomic factor & Official s & tandard & Results of measurement & Complies \\
\hline Lighting levels & $\begin{array}{l}\text { NOM-025-STPS-2008, lighting } \\
\text { conditions in workplace, determine } \\
\text { the minimum lighting levels that } \\
\text { must affect the work plane, for each } \\
\text { type of visual task or work area [19]. }\end{array}$ & $\begin{array}{l}\text { Minimum lighting levels: } \\
\text { interior-50 lux; simple visual } \\
\text { requirement: } 200 \text { lux; moderate } \\
\text { detail distinction: } 300 \text { lux }\end{array}$ & $\begin{array}{l}\text { Interior: } 104 \text { lux; simple } \\
\text { visual requirement: } 220 \text { lux; } \\
\text { moderate detail distinction; } \\
\quad 308 \text { lux }\end{array}$ & $\nabla$ \\
\hline Noise levels & $\begin{array}{l}\text { NOM-011-STPS-2001, safety and } \\
\text { hygiene conditions in workplace } \\
\text { where noise is generated determine } \\
\text { the maximum permissible limits of } \\
\text { exposure of workers to stable, } \\
\text { unstable, or impulsive noise during } \\
\text { the exercise of their duties [20]. }\end{array}$ & $\begin{array}{l}\text { During a maximum permissible } \\
\text { exposure time of } 8 \text { hours, a noise } \\
\text { exposure level of } 90 \mathrm{~dB} \text { is allowed. }\end{array}$ & $\begin{array}{l}\text { Minimum: } 77 \mathrm{~dB} \\
\text { Maximum: } 88.8 \mathrm{~dB}\end{array}$ & $\nabla$ \\
\hline $\begin{array}{l}\text { Thermal } \\
\text { environment }\end{array}$ & $\begin{array}{l}\text { NOM-001-STPS-2008, artificial } \\
\text { ventilation for worker comfort or } \\
\text { due to the requirements of activities } \\
\text { in the workplace [21]. } \\
\text { NOM-015-STPS-2001, maximum } \\
\text { permissible limits of exposure to } \\
\text { high thermal conditions [22]. }\end{array}$ & $\begin{array}{l}\text { Relative humidity between } 20 \% \text { and } \\
60 \% \text {. Air temperature of } 22^{\circ} \mathrm{C} \pm 2^{\circ} \mathrm{C} \\
\text { for times of cold environment and } \\
24.5^{\circ} \mathrm{C} \pm 1.5^{\circ} \mathrm{C} \text { for hot times. } \\
\text { Maximum allowable temperature in } \\
\text { a light duty regime } 30^{\circ} \mathrm{C} \text {. }\end{array}$ & $\begin{array}{l}\text { Humidity: } 30 \% \text { to } 41 \% \\
\text { Temperature: } 26^{\circ} \mathrm{C} \text { to } 28^{\circ} \mathrm{C}\end{array}$ & $\nabla$ \\
\hline
\end{tabular}

\section{Conclusions}

The method of evaluating the effect of the design and the environmental conditions of the manufacturing cells provides clear and simple steps to determine if the worker works under optimal conditions, which affects his work performance. The analysis of operations seeks to identify operating times, dead times, sequence in operations, and bottlenecks in order to optimize the process and facilitate and adapt the work to the worker, which is why the design and the environmental conditions of the cell to analyse the possible effects it may have on the health and wellbeing of the worker and to be able to carry out action plans to counteract them.

Official standards establish the appropriate parameters for each environmental factor to comply with health and safety regulations. However, it was observed that changes in official lighting and noise standards are required, determining the possible effects on worker health. If the use of LED lighting is increasing given its benefits, such as offering different white temperatures such as warm, neutral, and cold, it will be necessary to expand the parameters of lighting levels [23]. Regarding noise levels, many companies are currently opting to extend their working hours, and the official standard does not indicate the maximum permissible exposure limits during 12-hour long shifts [24, 25].

\section{Data Availability}

The data used to support the findings of this study are included within the article.

\section{Conflicts of Interest}

The authors declare no conflicts of interest with respect to the research, authorship, and/or publication of this article.

\section{Acknowledgments}

Authors are greatly grateful to the Universidad Autónoma de Baja California for facilitating access and use of their facilities and equipment to carry out this research.

\section{References}

[1] D. S. Cochran, M. U. Jafri, A. K. Chu, and Z. Bi, "Incorporating design improvement with effective evaluation using the manufacturing system design decomposition (MSDD)," Journal of Industrial Information Integration, vol. 2, pp. 6574, 2016.

[2] L. P. S. Hartanti, "Work measurement approach to determine standard time in assembly line," International Journal of Management and Applied Science, vol. 2, no. 10, pp. 192-195, 2016.

[3] M. T. Gonçalves and K. Salonitis, "Lean assessment tool for workstation design of assembly lines," Procedia CIRP, vol. 60, pp. 386-391, 2017.

[4] J. Li, X. Tan, and J. Li, "Research on dynamic facility layout problem of manufacturing unit considering human factors," Mathematical Problems in Engineering, vol. 2018, Article ID 6040561, 2018.

[5] M. S. Andargie and E. Azar, "An applied framework to evaluate the impact of indoor office environmental factors on occupants' comfort and working conditions," Sustainable Cities and Society, vol. 46, p. 101447, 2019.

[6] J. Dul, R. Bruder, P. Buckle et al., "A strategy for human factors/ergonomics: developing the discipline and profession," Ergonomics, vol. 55, no. 4, pp. 377-395, 2012.

[7] A. S. Serdyukova, V. I. Salcutsan, O. N. Androsova, and D. B. Solovev, "Analysis and evaluation of factors of the production environment and labor process during a special assessment of working conditions in company "NPO SM"," IOP Conference Series: Earth and Environmental Science, vol. 459, no. 3, Article ID 032040, 2020.

[8] A. Sobhani, M. I. M. Wahab, and M. Y. Jaber, "The effect of working environment aspects on a vendor-buyer inventory 
model," International Journal of Production Economics, vol. 208, pp. 171-183, 2019.

[9] C. Bustos, D. Fischer, L. Ballardin, and R. Nielsen, "The ergonomic process of an automotive company in Brazil: a study case," Work, vol. 41, no. 1, pp. 5449-5452, 2012.

[10] A. García-Lallana, G. Viteri-Ramírez, R. Saiz-Mendiguren, J. Broncano, and J. Dámaso Aquerreta, "Ergonomics of the workplace in radiology," Radiología (English Edition), vol. 53, no. 6, pp. 507-515, 2011.

[11] M. Muzammil, S. Ahmad, A. A. Khan, and F. Hasan, "Design of a workstation and its evaluation under the influence of noise and illumination for an assembly task," Work, vol. 39, no. 1, pp. 3-14, 2011.

[12] S. Stansfeld and C. Clark, "Mental health effects of noise," Encyclopedia of Environmental Health, vol. 1, pp. 683-689, 2011.

[13] C. Clark and K. Paunovic, "WHO environmental noise guidelines for the European region: a systematic review on environmental noise and quality of life, wellbeing and mental health," International Journal of Environmental Research and Public Health, vol. 15, no. 11, p. 2400, 2018.

[14] R. D. Bruce, A. S. Bommer, K. A. Lefkowitz, and N. W. Hart, "Safe lifetime occupational exposure-1 LONE (lifetime occupational noise exposure)," The Journal of the Acoustical Society of America, vol. 127, no. 3, p. 1881, 2010.

[15] I. Dianat, A. Vahedi, and S. Dehnavi, "Association between objective and subjective assessments of environmental ergonomic factors in manufacturing plants," International Journal of Industrial Ergonomics, vol. 54, pp. 26-31, 2016.

[16] B. W. Niebel and A. Freivalds, Ingeniería Industrial de Niebel Métodos, Estándares y Diseño del TrabajoMc, Graw Hill, 12th edition, NewYork, NY, USA, 2014, https://www.academia.edu/7731445/Ingenier'1a_Industrial_12ma_Niebel_y_ Freivalds.

[17] P. R. Mondelo, E. Gregori, and P. Barrau, Ergonomia 1 Fundamentos, Alfaomega, México City, MX, USA, 3rd edition, 2000.

[18] A. Saptari, W. S. Lai, and M. R. Salleh, "Jig design, assembly line design and work station design and their effect to productivity," Jordan Journal of Mechanical and Industrial Engineering, vol. 5, no. 1, pp. 9-16, 2011.

[19] "Norma Oficial Mexicana NOM-025-STPS-2008, Condiciones de Iluminación en los Centros de Trabajo.” http:// asinom.stps.gob.mx:8145/upload/noms/Nom-025.pdf.

[20] "Norma Oficial Mexicana NOM-011-STPS-2001, Condiciones de Seguridad e Higiene en los Centros de Trabajo donde se genere Ruido." http://www.dof.gob.mx/nota_ detalle.php? codigo $=734536 \&$ fecha $=17 / 04 / 2002$.

[21] "Secretaria del Trabajo y Previsión Social Norma Oficial Mexicana NOM-001-STPS-2008, Edificios.” http://www.stps. gob.mx/bp/secciones/dgsst/normatividad/normas/Nom-001. pdf.

[22] "Norma Oficial Mexicana NOM-015-STPS-2001, Condiciones Térmicas Elevadas o Abatidas-Condiciones de Seguridad e Higiene." http://asinom.stps.gob.mx:8145/ upload/noms/Nom-015.pdf.

[23] J. M. Orbaneja, A. Álvarez, J. López-Beceiro, R. Artiaga, and B. Álvarez, "Analysis of LED lighting for a service ship," Renewable Energy and Power Quality Journal, vol. 1, no. 13, pp. 675-679, 2015.

[24] M. Alidosti, A. B. Heydarabadi, Z. Baboli, H. Nazarbigi, and M. Mobasheri, "Association between job burnout and noise pollution among nurses in Behbahan city, Iran," Journal of
Fundamentals of Mental Health, vol. 18, no. 2, pp. 103-108, 2017.

[25] M. Estryn-Béhar and B. I. J. M. Van Der Heijden, "Effects of extended work shifts on employee fatigue, health, satisfaction, work/family balance, and patient safety," Work, vol. 41, no. 1, pp. 4283-4290, 2012. 